\title{
Effects of Instructional Materials on Secondary Schools Students' Academic Achievement in Social Studies in Ekiti State, Nigeria
}

\author{
Abdu-Raheem Bilqees Olayinka ${ }^{1, *}$ \\ ${ }^{1}$ Department of Social Science Education, Faculty of Education, Ekiti State University, Ado-Ekiti, Nigeria \\ *Correspondence: Department of Social Science Education, Faculty of Education, Ekiti State University, Ado-Ekiti, \\ Nigeria. Tel: 234-806-089-4068. E-mail: dr_boabduraheem@yahoo.com
}

Received: December 13, 2015

Accepted: January 4, 2016 Online Published: February 9, 2016

doi:10.5430/wje.v6n1p32

URL: http://dx.doi.org/10.5430/wje.v6n1p32

\begin{abstract}
The aim of this paper is to highlight the contribution of instructional materials to the academic achievement of secondary school students in Social Studies in Ekiti State. The population for the study comprised of all Junior Secondary School Class II students from among which 180 were sampled. The instrument for the study is a 30 multiple-choice self- designed Social Studies Achievement Test (SSAT). The instrument was validated by specialists in Social Studies Test and Measurement and Educational Management. Test-re-test method and estimation of internal consistency was used to ascertain the reliability. The reliability co-efficients of 0.73 and 0.75 were obtained respectively. The study generated four hypotheses that were tested at the significance level of 0.05 . ANOVA and ANCOVA statistical tools were used to analyse the data collected. The study found that there was a significant difference in the pre-test and post-test of students in the experimental group. The study also found that gender effect was not statistically significant in social studies. The study concluded that students who were taught with instructional materials performed better than those taught without. The study therefore recommended that teachers of Social Studies should employ the use of essential instructional materials for their teaching and also improvise where and when the materials are not available. It therefore becomes imperative to have concerted efforts among parents, school and the government to make available important and necessary instructional materials to teachers of Social Studies for enhanced teaching and consequents improved achievement of students in the subject.
\end{abstract}

Keywords: instructional materials; students; academic achievement; secondary school; ekiti state

\section{Introduction}

Social Studies is a study connected with all aspects of human beings to enable them live a fulfilled, comfortable and full of achievement life. It study people in relation to the social, academic, economic, cultural, physical and psychological lives. It has to do with all round development of human beings to enable them become useful citizens in the society. Wesley in Kochhar (2012) saw Social Studies as those portions of the Social Sciences selected for instructional purposes applied to include anything pertinent to the immediate purpose of learning and adapted to the level of comprehension of the student. Abdu-Raheem (2011) observed that the objectives of Social Studies is yet to be achieved as a result of poor teaching and lack or inadequacy of instructional materials to motivate students.Ofuani (2014) also attested to inadequacy of instructional materials and resources in all the schools sampled in his study.

Instructional materials are essential and significant tools needed for teaching and learning of school subjects to promote teachers'efficiency and improve students' performance. They make learning more interesting, practical, realistic and appealing. They also enable both the teachers and students to partcipate actively and effectively in lesson sessions. They give room for acquisition of skills and knowledge and development of self- confidence and self- actualization. Ibeneme (2000) defined teaching aids as those materials used for practical and demonstration in the class situation by students and teachers. Ikerionwu (2000) saw instructional materials as objects or devices that assist the teacher to present a lesson to the learners in a logical and manner.

In his own perspective, Fadeiye (2005) saw instructional materials as visual and audio-visual aids, concrete or non-concrete, used by teachers to improve the quality of teaching and learning activities in Social Studies. Agina-Obu (2005) submitted that instructional materials of all kinds appeal to the sense organs during teaching and 
learning. Isola (2010) also described instructional materials as objects or devices that assist the teachers to present their lessons logically and sequentially to the learners.Oluwagbohunmi and Abdu-Raheem (2014) acknowledged that instructional materials are such used by teachers to aid explanations and make learning of subject matter understandable to students during teaching learning process.

In the same vein, Obanya (2004) asserted that several studies carried out in some areas in Nigeria indicated that the results of Senior School Certificate Examinations was completely bad in nearly all subjects offered by the students. He stressed further that only about $10 \%$ of candidates 'meaningfully passed' the examination.Abdu-Raheem (2011) asserted that non availability and inadequacy of instructional materials are major causes of ineffectiveness of the school system and poor performance of students in schools. Ahmed (2003) confirmed that in most secondary schools in Nigeria, teaching and learning take place under a most un-conducive environment without access to essential materials. Eniayewu (2005) posited that it is very important to use instructional aids for instructional delivery to make students acquire more knowledge and to promote academic standard.

In addition, Ajayi and Ayodele (2001) stressed the importance of availability of instructional materials to achieving effectiveness in educational delivery and supervision in the school system. Ogbondah (2008) alerted on the gross inadequacy and under utilization of instructional materials necessary to compensate for the inadequacies of sense organs and to reinforce the capacity of dominant organs.He noted that school teachers should try their possible best in the provision of locally made materials in substitution for the standard ones to promote their lessons.Enaigbe (2009) noted that basic materials such as textbooks, chalkboard and essential equipment like computer, projector, television and video are not readily available in many schools.

In a own study, Olumorin, Yusuf, Ajidagba and Jekayinfa (2010) observed that instructional materials help teachers to teach conveniently and the learners to learn easily without any problem. They asserted that instructional materials have direct contact with all sense organs. Kochhar (2012) supported that instructional materials are very significant learning and teaching tools. He suggested the needs for teachers to find necessary materials for instruction to suplement what textbooks provide in order to broaden concepts and arouse students'interests in the subject.According to Abolade (2009), the advantages of instructional materials are that they are cheaper to produce, useful in teaching large number of students at a time, encourage learners to pay proper attention and enhance their interest.

However, Akinleye (2010) attested that effective teaching and learning requires a teacher to teach the students with instructional materials and use practical activities to make learning more vivid, logical, realistic and pragmatic.Esu, Enukoha and Umoren (2004) agreed that instructional materials are indispensable to the effective teaching and learning activities. Ekpo (2004) also supported that teaching aids are always useful in supporting the sense organs. Despite the fact that instructional materials are essential tools that can make learning practical and knowledge acquisition easier, they are not readily available in Nigerian secondary schools leading to low level of performance of learners in government examinations (Abdu-Raheem 2014).

According to Josua in Abiodun-Oyebanji and Adu(2007), instructional materials are all things that are used to support, facilitate, influence or encourage acquisition of knowledge, competency and skills. Abdu-Raheem (2014) encouraged teachers to improvise teaching aids because they are in great measure enhance learners' full participation in the lesson, gives room for inquiry, problem-solving, discussion and clarification of issues and ideas among students and the teacher. Riveire (2006) noted that improvisation is a valuable teaching tool. Afolabi and Adeleke (2010) identified non-availability, inadequacy and non utilization of learning materials as a result of teacher's poor knowledge as factors responsible for the use of lecture method. They recommended that both students, teachers, parents, Parents/Teacher Association, government and philanthropists shouldbe involved in improvising instructional materials for the teaching and learning in schools.

Therefore, Ogbondah (2008) advocated for of teachers'resourcefulness and also encouraged them to search for necessary instructional materials through local means to supplement or replace the standard ones. Oso (2011) also agreed that the best way for teachers to make use of their manipulative skills is to improvise so as to achieve their lesson objectives at least to a reasonable extent.Jekayinfa (2012) also identified the importance of improvisation of instructional materials as making learning concrete and real, substitutesone thing for another, allows the students to participate in the production of materials, economical and more teacher-student resource oriented. Abdu-Raheem (2014) submitted that improvisation of locally made teaching aids could assist to improve quality of graduates turn out from schools and standard of education generally. Abdu-Raheem and Oluwagbohunmi (2015) also corroborated the idea that resourceful and skillful teachers should improvise necessary instructional materials to promote academic standard in Nigerian schools. 


\section{Statement of the Problem}

One of the major problems facing education sector in Nigeria is the low level of the performance of secondary school students in both local and standardized examinations. It has become a great concern for researchers, educators and all education stake-holders over the years. It was observed that students usually fail in examinations owing to improper teaching methods and lack of essential teaching aids for instructional delivery. (Afolabi, 2009). This study therefore deemed it necessary to look specifically into the contributions of instructional materials to academic achievement of secondary school students in Social Studies.

\section{Research Hypotheses}

The following hypotheses were generated for the study:

1. The achievement mean scores of students will not be significantly different in the experimental and control groups

2. The achievement mean scores of male students will not be significantly different in the experimental and control groups.

3. The achievement mean scores of female students will not be significantly different in the experimental and control groups.

4. The achievment of students in Social Studies will not be significantly different based on gender.

\section{Methodology}

The study is a quasi-experimental pre-test, post-test, control group design. The pre-test was used to test the previous knowledge of the students used for the study and post-test to measure their level of achievement. One group was assigned to experimental while the other to control. The two groups responded to pre-test before the experiment took place. Various instructional materials such as maps, charts, pictures, diagrams, stamps, envelops, handsets, land phone boxes, hand bells, news papers, magazines, radio, television sets, computers and projectors were used to teach students in the experimental group while the control group was taught with normal conventional method without any teaching aid. After the treatment lessons for the experimental group, the post-test was administered on the two groups to test their level of achievement. The population for the study wasall Junior Secondary School students in Ekiti State while the sample was 180 Junior Secondary School Class II students selected from three schools. Purposive sampling was used to select two single-sex schools (one boys only and the other girls only) while simple random sampling was used to select one co-educational school. 60 students were selected from each single-sex school through simple random sampling while stratified sampling was used to select 30 boys and 30 girls from the co-educational school. The grouping of the students into experimental and control groups was also done through simple random sampling technique. However 45 boys and 45 girls were allocated in each group.

The instrument for the study was a self-designed onetitled "Social Studies Achievement Test (SSAT). It was made up of 30 multiple-choice items based on transportation and communication systems in Nigeria. The instrument was validated by Social Studies, Test and Measurement and Educational Management specialists. Test-re-test and estimation of internal consistency were used to determine the reliability of the instrument.The test-re-test of the instrument was done by giving it as a test to 30 students from 2 schools that were not part of the study. After six weeks, the same set of students were given the same test. Pearson Product Moment Correlation Coefficient Analysis was used to determine the scores of the two sets. The correlation coefficient of 0.73 was obtained. The estimation of internal consistency was also determined by application of Crombach Alpha on the responses of 30 students from a school that was not part of the study. The reliability co-efficient of 0.75 was also obtained. The reliability is okay to measurethe differences between experimental and control groups in the case of large sample. ANOVA and ANCOVA statistical tools were used for analyses of the data collected.

\section{Results}

Hypothesis 1: The achievement mean scores of students will not be significantly different in the experimental and control groups 
Table 1. ANCOVA Showing the Achievement Mean Scores of Students by Treatment.

\begin{tabular}{lccccc}
\hline \multicolumn{1}{c}{ Source } & SS & df & Ms & F-cal & F-table \\
\hline Corrected Model & 7722.466 & 2 & 3861.233 & 314.235 & 3.04 \\
Covariate (Pretest) & 0.016 & 1 & 0.016 & 0.001 & 3.89 \\
Group & 7716.266 & 1 & 7716.266 & 627.965 & 3.89 \\
Error & 2174.928 & 177 & 12.288 & & \\
Corrected Total & 9897.394 & 179 & & & \\
Total & 130695.000 & 180 & & & \\
\hline
\end{tabular}

$\mathrm{P}<0.05$

Table 1 shows that F-cal (627.965) is greater than F-table (3.04) at 0.05 level of significance. This implies that there is significant difference between the achievement mean scores of students in the experimental and control groups. The null hypothesis is therefore rejected. The Multiple Classification Analysis showing the effect of treatment on adjusted mean scores is depicted in Table 2.

Table 2. Multiple Classification Analysis Showing Students’ Adjusted Mean Scores by Treatment

\begin{tabular}{llcccc}
\hline \multicolumn{1}{c}{$\begin{array}{c}\text { Variable }+ \\
\text { Category }\end{array}$} & $\mathrm{N}$ & $\begin{array}{c}\text { Unadjusted } \\
\text { Deviation }\end{array}$ & Eta & $\begin{array}{c}\text { Adjusted for Independent }+ \\
\text { Covariate }\end{array}$ & Beta \\
\hline $\begin{array}{l}\text { Experimental } \\
\text { Control }\end{array}$ & 90 & 6.55 & 6.54 & 0.03 \\
Multiple R & 90 & -6.55 & & -6.54 & \\
Multiple R ${ }^{2}$ & 0.025 & & & & \\
\hline
\end{tabular}

Table 2 shows that students in the experimental group that were taught with instructional materials had higher adjusted mean score of $32.45(25.91+6.54)$ than those in the control group that have no access to instructional materials with an adjusted mean score of $19.37(25.91+(-6.54)$. This implies that the use of instructional materials will greatly enhance students' academic achievement in Social Studies.

Hypothesis 2:The achievement mean scores of male students will not be significantly different in the experimental and control groups.

Table 3. ANCOVA Showing the Achievement Mean Scores of Male Students by Treatment

\begin{tabular}{lccccc}
\hline \multicolumn{1}{c}{ Source } & SS & Df & Ms & F-cal & F-table \\
\hline Corrected Model & 4216.715 & 2 & 2108.345 & 259.943 & 3.04 \\
Covariate (Pretest) & 0.573 & 1 & 0.573 & 0.071 & 3.89 \\
Group & 4205.529 & 1 & 4205.529 & 518.503 & 3.89 \\
Error & 705.649 & 87 & 8.111 & & \\
Corrected Total & 4922.400 & 89 & & & \\
Total & 66388.000 & 90 & & & \\
\hline
\end{tabular}

$\mathrm{P}<0.05$

F-table which is 3.89 is less than F-calculated which is (518.503) at 0.005 significant level. The null hypothesis is therefore not accepted $(\mathrm{F}=518.503, \mathrm{P}<0.05)$. This is an indication that male students that have access to instructional materials in the experimental group performed excellently better in Social Studies than other males that were not taught with instructional materials. The Multiple Classification Analysis of adjusted mean scores of male subjects in Social Studies by treatment is shown in Table 4. 
Table 4. Multiple Classification Analysis of Male Students' Adjusted Mean Scores by Treatment

\begin{tabular}{lcccc}
\hline Grand Mean $=26.13$ & & & & \\
\hline $\begin{array}{l}\text { Variable }+ \\
\text { Category }\end{array}$ & $\mathrm{N}$ & $\begin{array}{c}\text { Unadjusted } \\
\text { Deviation }\end{array}$ & Eta & $\begin{array}{c}\text { Adjusted for Independent }+ \\
\text { Covariate }\end{array}$ \\
\hline Experimental & 45 & 6.85 & -0.25 & 6.83 \\
Control & 45 & -6.84 & & -6.83 \\
\hline Multiple & 0.048 & & & -0.05 \\
Multiple $\mathrm{R}^{2}$ & 0.002 & & & \\
\hline
\end{tabular}

Table 4 reveals that with a grand mean score of 26.13, male students taught with instructional materials had an adjusted mean score of $32.96(26.13+6.83)$ while those in the control group obtained an adjusted mean score of $19.30(26.13+(-6.83)$. It implies that the use of instructional materials during classroom lesson will correspondingly enhance the students' academic achievement of male students in Social Studies.

Hypothesis 3: The achievement mean scores of female students will not be significantly different in the experimental and control groups.

Table 5. ANCOVA Summary of Female Students' Achievement Mean Scores by Treatment

\begin{tabular}{lccccc}
\hline \multicolumn{1}{c}{ Source } & SS & Df & Ms & F-cal & F-table \\
\hline Corrected Model & 3523.515 & 2 & 1761.758 & 106.282 & 3.04 \\
Covariate (Pretest) & 1.638 & 1 & 1.638 & 0.099 & 3.89 \\
Group & 3480.599 & 1 & 3480.599 & 209.974 & 3.89 \\
Error & 1442.140 & 87 & 16.576 & & \\
Corrected Total & 4965.656 & 89 & & & \\
Total & 64307.000 & 90 & & & \\
\hline
\end{tabular}

$\mathrm{P}<0.05$

Table 5 shows that F-table (3.89)is less than F-cal (209.974) at 95\% confidence level. Therefore, there is significant difference between the achievement mean scores of female students in the experimental and control groups. Multiple Classification Analysis of adjusted mean scores of female subjects by treatment is presented in Table 6 .

Table 6. Multiple Classification Analysis of Female Students' Adjusted Mean Scores by Treatment

\begin{tabular}{lcclll}
\hline Grand Mean $=25.68$ & \multicolumn{1}{l}{} & & & \\
\hline $\begin{array}{l}\text { Variable } \\
\text { Category }\end{array}$ & $\mathrm{N}$ & $\begin{array}{l}\text { Unadjusted } \\
\text { Deviation }\end{array}$ & Eta & $\begin{array}{l}\text { Adjusted for Independent }+ \\
\text { Covariate }\end{array}$ & Beta \\
\hline Experimental & 45 & 6.25 & 6.19 & -0.09 \\
Control & 45 & -6.26 & -0.46 & -6.20 & \\
\hline Multiple R & 0.093 & & & & \\
Multiple $\mathrm{R}^{2}$ & 0.009 & & & & \\
\hline
\end{tabular}

Table 6 shows that female studentsin the experimental group that were taught using instructional materials had an adjusted mean score of $31.87(25.68+6.19)$ while the female students in control group that have no access to instructional materials had an adjusted mean score of $19.48(25.68+(-6.20)$. This shows that the use of instructional materials will automatically enhance the academic achievement of female students in Social Studies.

Hypothesis 4: The achievment of students in Social Studies will not be significantly different based on gender and treatment. 
Table 7. $2 \times 2$ ANCOVA of Gender and Treatment on Students' Achievement in Social Studies

\begin{tabular}{lccccc}
\hline Source & SS & Df & Ms & F-cal & F-table \\
\hline Corrected Model & 7747.572 & 4 & 1963.893 & 157.667 & 2.42 \\
Covariate (Pretest) & 0.178 & 1 & 766.347 & 62.382 & 3.89 \\
Gender & 9.367 & 1 & 9.367 & 0.763 & 3.89 \\
Group & 7714.848 & 1 & 7714.848 & 628.005 & 3.89 \\
Gender * Group & 15.757 & 1 & 15.757 & 1.283 & 3.89 \\
Error & 2149.822 & 175 & 12.285 & & \\
Corrected Total & 9897.394 & 179 & & & \\
Total & 130659.000 & 180 & & & \\
\hline
\end{tabular}

$\mathrm{P}<0 . \overline{05}$

Table 7 shows that F-cal (1.283)is less than F-table which is (3.89) at 0.05 significant level. Therefore, there is no significant interaction effect of treatment and gender on students' ahievement in Social Studies $(\mathrm{F}=\mathrm{P}>0.05)$. The null hypothesis is therefore accepted. However, gender has no statistical significant effect on theacademic achievement of students in Social Studies. $(F=p>0.05)$. Again, the main effect of treatment on the achievement mean scores of students is significant at 0.05 level $(\mathrm{F}=\mathrm{P}<0.05)$.

\section{Discussion}

This study found that students in the experimental group performed better than students in the control group in their achievement mean scores. The study corroborates the findings of Esu, Enukoha and Umoren (2004) found that teaching aids are indispensable to the effective teaching and learning activitiesand successful instructional delivery in schools. Hence, instructional materials are necessary to enable students acquire better knowledge and skills.

This study also confirmed that themale students in the experimental group have better statistically significant mean scores and greater achievement than the male studentsin the control groups. The male students taught with instructional materials performed excellently than those who were taught without them. The findings is consistent with the opinion of Atanda and Jaiyeoba (2011) who submitted that availability and adequacy of instructional materials enhance effective learning and better performance of students .

The study discovered that there is statistical significant difference between the achievement mean scores of female students in the experiemental and control groups. The study is in line with that of Onasanya and Omosewo (2011) who reported that female students that were taught with the use of instructional materials performed better than others taught with conventional method without any material.

This findings also indicated that there is no significant interraction effect of treatment and gender on students' achievement in Social Studies. The findings is contrary to Okoye (2009) which revealed interaction effects of gender on students' academic performance However, the study is in agreement with the opinion of Oladejo, Olosunde, Ojebisi and Isola (2011) and Muodumogu and Yisa (2013) who found that gender has no significant effects on the academic achievement of students in Physics.

\section{Conclusion}

The study concluded that the importance of instructional materials in the development of learners' intellectual abilities and attainment of teaching/learning objectives cannot be over-emphasized. The students taught with instructional materials have excellent achievement scores compared with those taught without any material. It was also noted in the study that there is no significant interaction effect of treatment and gender on students' achievement in Social Studies.

\section{Recommendations}

Based on the findings, the following recommendations were therefore made:

1. Students should corroborate the efforts of other stakeholders in improvisation of instructional materials to enhance learning and promote academic performance in schools.

2. Teachers should always try their best to make use of available instructional materials where necessary to make their lessons more interesting. 
3. Teachers of Social Studies are encouraged to search for necessary instructional materials that can appeal to the senses of learners, arouse their interest, encourage their participation, make learning more meaningful and promote academic standard.

4. Parents should be ready to cooperate with teachers in the provision and improvisation of instructional materials for better instructional delivery in schools.

5. School principals should provide Social Studies teachers with enabling environment for the use of available instructional material to gives room for participatory studentship and make learning more meaningful.

6. School principals should also encourage improvisation of instructional materials by students, teachers, the schools parents and the government to enhance teaching/learning in schools and promote academic standard.

7. Government should supply teaching aids and finance schools to improvise unavailable and inadequate instructional materials to make teaching and learning easier, practical, appealing and enjoyable.

\section{References}

Abdu-Raheem, B. O. (2011). Availability, adequacy and utilisation of social studies instructional materials in Ekiti State secondary schools. Journal of Current Discourse and Research, 3, 242-255.

Abdu-Raheem, B. O. (2014). Improvisation of instructional materials for teaching and learning in secondary schools as predictor of high academic standard. Nigerian Journal of Social Studies, XVII(1), 131-143.

Abdu-Raheem, B.O., \& Oluwagbohunmi, M.F. (2015). Pre-service teachers' problems of improvisation of instructional materials in social studies in Ekiti State University. Journal of Education and Practice, 6(3), 160-163.

Abiodun-Oyebanji, O., \& Adu, E.T. (2007). Principals' performance in instructional supervision in the use of resources in senior secondary schools in Ekiti State. Journal of Educational Focus, 1(1), 8-14.

Abolade, A.O. (2009). Basic criteria for selecting and using learning and instructional materials. In I.O. Abimbola \& A.O. Abolade (Eds.), Fundamental principles and practice of instruction, Department of Science Education, Ilorin. pp 497-504.

Afolabi, S.S. (2009). Teaching method and textual material variables as correlate of students' learning outcomes in senior secondary school mathematics. Ph.D. Post-field Seminar Department of Teacher Education, University of Ibadan.

Afolabi, S.S., \& Adeleke, J.O. (2010). Assessment of resources and instructional materials status in the teaching of mathematics in south western Nigeria. European Journal of Scientific Research, 43(1), 406-410.

Agina-Obu, T.N. (2005). The relevance of instructional materials in teaching and learning. In I.Robert-Okah \& K.C. Uzoeshi (Eds.), Theories and practice of teaching, Port Harcourt: Harey publication.

Ahmed, T.M. (2003). Education and national development in Nigeria. Journal of Studies in Education, 10, 35-46.

Ajayi, I.A., \& Ayodele, J.B. (2001). An introduction to educational planning:Administration and supervision. Ado-Ekiti: Yemi Prints Publishing Services.

Akinleye, G.A. (2010). Enhancing the quality of life in this complicated but dynamic world. 25th Inaugural lecture, University of Ado-Ekiti, April 6.

Atanda, A.I., \& Jaiyeoba, A.O. (2011). Effects of school-based quality factors on secondary school students' achievement in English language in South-Western and North-Central Nigeria. Journal of Emerging Trends in Educational Research and policy Studies, 2(2), 93-99.

Ekpo, O. E. (2004). Instructional strategies and the challenges of implementing school curriculum in Nigeria, Lead paper preseented at 17th Annual Conference of the Curriculum Organisation of Nigeria (CON) held at University of Uyo, Uyo, Akwa Ibom State, 14th - 17th September.

Enaigbe, A. P. (2009). Strategies for improving supervisory skills for effective primary education in Nigeria. Edo Journal of Counselling, 2(2), 235-244.

Eniayewu, J. (2005). Effect of instructional materials on teaching of economics in secondary schools in Akoko North-East Local Governemnt Area of Ondo State. Ikere Journal of Education, 7, 117-120. 
Esu, A.E.O., Enukoha, O.I.T., \& Umorem, G. U. (2004). Curriculum development in Nigeria for colleges and universities. Owerri: Whyte and Whyte Publishers.

Fadeiye, J.O. (2005). A social studies textbook for colleges and universities. Ibadan: Akin-Johnson Press and Publishers.

Ibeneme, O.T. (2000). Provision and utilization of instructional equipment for teaching and learning science and technology. Issues in Educational Journal, 1, 139-144.

Ikerionwu, J.C. (2000). Importance of aids and resources in classroom teaching. In A.M. Oyeneyin (Ed.), Perspective of classroom teaching. Abuja: Martmonic Investment Ltd.

Isola, O.M. (2010). Effect of standardized and improvised instructional materials on students academic Achievement in secondary school physics. Unpublished M. Ed. project, University of Ibadan, Ibadan.

Jekayinfa, A.A. (2012). Fundamentals of instructional methods. Ilorin, Kwara State, Olives Production Ltd.

Kochhar, S. K. (2012). The teaching of social studies. New Delhi, India. Sterling Publishers Private Limied.

Muodumogu, C.A., \& Yisa, T.A. (2013). Writing skills development strategies and junior secondary schools' achievement in composition. Journal of the Reading Association of Nigeria (RAN), 14(1), 107-117.

Obanya, P. (2004). The dynamics of secondary education: A synthesis of studies in four states of the federation. Washington D.C: The World Bank.

Ofuani, F.N. (2014). Learning environment for literacy development. Journal of the Reading Association of Nigeria(RAN), 15(2), 301-307.

Ogbondah, L. (2008). An appraisal of instructional materials used to educate migrant fishermen's children in Rivers State, Nigeria. International Journal of Scientific Research in Education, 1(1), 13-25.

Okoye, N.S. (2009). The effects of the writing process method on students' performance in English composition, Ph. D Thesis. University of Nigeria, Nsukka.

Oladejo, M.A., Olosunde, G.R., Ojebisi, A.O., \& Isola, O.M. (2011). Instructional materials and students'academic achievement in physics. Some Policy Implications. European Journal of Humanities and Social Sciences, 2(1), 112-126.

Olumorin, C. O., Yusuf, A., Ajidagba, U. A., \& Jekayinfa, A. A. (2010). Development of Instructional materials from local resources for art-based courses. Asian Journal of Information Technology, 9(2), 107-110. http://dx.doi.org/10.3923/ajit.2010.107.110

Oluwagbohunmi, M.F., \& Abdu-Raheem, B.O. (2014). Sandwich undergraduates' problem of improvisation of instructional materials in social studies: The case of Ekiti State University. Journal of International Academic Research for Multidisciplinary, 1(12), 824-831.

Onasanya, S.A., \& Omosewo, E.O. (2011). Effect of improvised and standard instructiional materials on secondary school students' academic performance in Physics in Ilorin, Nigeria. Singapore Journal of Scientific Research, 1(1), 68-76. http://dx.doi.org/10.3923/sjsres.2011.68.76

Oso, L. (2011). Need for improvisation in classroom teaching. The Punch, June 20.

Riveire, J. (2006). Using improvisation as a teaching strategy. Music Educators Journal, 9(3), 40-45. http://dx.doi.org/10.2307/3401139 